\title{
Pengaruh lokasi terhadap serangan lalat puru Cecidochares connexa (Macquart) pada tumbuhan eksotik invasif Chromolaena odorata (L.) King \& Robinson dan interaksinya dengan komunitas serangga lokal
}

\author{
Effects of locations on gall fly Cecidochares connexa (Macquart) \\ attacks on invasive exotic plant Chromolaena odorata (L.) King \& \\ Robinson and its interaction with local insect communities
}

\author{
Luna Lukvitasari ${ }^{*}$, Hermanu Triwidodo ${ }^{1}$, Akhmad Rizali $^{2}$, Damayanti Buchori ${ }^{1,3}$ \\ ${ }^{1}$ Departemen Proteksi Tanaman, Fakultas Pertanian, IPB University \\ Jalan Kamper, Kampus IPB Dramaga, Bogor 16680, Indonesia \\ ${ }^{2}$ Jurusan Hama dan Penyakit Tumbuhan, Fakultas Pertanian, Universitas Brawijaya \\ Jalan Veteran, Malang 65145, Indonesia \\ ${ }^{3}$ Center for Transdisciplinary and Sustainability Sciences (CTSS), IPB University \\ Jalan Raya Pajajaran No. 27, Bogor 16128
}

(diterima Juli 2020, disetujui Maret 2021)

\begin{abstract}
ABSTRAK
Lalat puru Cecidochares connexa (Macquart) (Diptera: Tephritidae) pertama kali diintroduksi ke Indonesia untuk mengendalikan gulma invasif Chromolaena odorata (L.) King \& Robinson atau kirinyuh. Tujuan dari penelitian ini adalah untuk mengetahui pengaruh tipe dan lokasi habitat, dan keberadaan musuh alami yang berhubungan dengan lalat puru terhadap tingkat serangannya. Penelitian dilakukan di berbagai tipe habitat di Bogor dan Lampung Selatan dari bulan Januari hingga Desember 2019. Tiga puluh sampel tanaman diperoleh dengan menggunakan metode kurva spesies area. Pengambilan sampel dilakukan dengan cara mengumpulkan puru di setiap lokasi dan habitat, kemudian dilakukan pemeliharaan puru selama \pm 1 bulan untuk melihat serangga yang keluar dari dalam puru di Laboratorium Pengendalian Hayati, Departemen Proteksi Tanaman, Fakutas Pertanian, IPB University. Hasil penelitian ini menunjukkan bahwa lokasi pengamatan mempengaruhi tingkat serangan lalat puru terhadap kirinyuh dan parasitisasi lalat puru oleh parasitoid, sedangkan habitat tidak mempengaruhi keduanya. Kemudian, terdapat serangga lain yang berasosiasi dengan kirinyuh selain lalat puru di dalam puru, yaitu Lonchaea sp.
\end{abstract}

Kata kunci: Chromolaena odorata, Cecidochares connexa, spesies invasif

\begin{abstract}
The gall fly, Cecidochares connexa (Macquart) was first introduced to Indonesia to control the invasive weed Chromolaena odorata (L.) King \& Robinson or kirinyuh. The purpose of this study was to determine the effect of habitat type and location, and the presence of natural enemies associated with gall flies on their level of attack. This research was be conducted in various types of habitat in Bogor and South Lampung from January to December 2019. Thirty plant samples were obtained using the area species curve method. Sampling was conducted to collect gall in each habitat, it was followed by rearing gall for \pm 1 month to see insects that came out from the gall at the Biological Control
\end{abstract}

* Penulis korespondensi: Luna Lukvitasari. Program Studi Entomologi, Sekolah Pascasarjana, IPB University, Jalan Kamper, Kampus IPB

Dramaga, Bogor 16680, Indonesia, Tel: 0251-8629364, Faks: 0251-8629363, Email: lukvitasariluna12@gmail.com 
Laboratory, Department of Plant Protection, Faculty of Agriculture, IPB University. The results of this study indicate that the location of the observation affects the level of attack on gall flies against kirinyuh and parachitization of gall flies by parasitoid, while the habitat does not affect both. Then there are other insects associated with kirinyuh in addition gall flies in gall, namely Lonchaea sp.

Key words: Chromolaena odorata, Cecidochares connexa, invasive spesies

\section{PENDAHULUAN}

Invasi spesies eksotik merupakan salah satu ancaman terbesar bagi keanekaragaman hayati (Loveridge et al. 2016) karena dapat menjadi komponen utama dalam perubahan lingkungan global, ancaman terhadap keanekaragaman hayati dan spesies lokal, penyebab terjadinya perubahan struktur dan fungsi ekosistem serta hilangnya fungsi biodiversitas (Jose et al. 2009; Charles \& Dukes 2008). Spesies eksotik invasif didefinisikan sebagai spesies asing yang pada umumnya diintroduksi oleh manusia kemudian mengancam ekosistem, habitat atau spesies lainnya, serta menyebabkan perubahan signifikan pada lingkungan (Pejchar \& Mooney 2009).

Chromolaena odorata (L.) King \& Robinson atau kirinyuh merupakan tumbuhan invasif yang berasal dari Florida, Amerika Serikat yang kemudian menyebar luas ke Asia dan Afrika (Gautier 1992). Persebaran tumbuhan ini telah mencapai Asia Tenggara termasuk Indonesia dan Australia yang telah berubah status menjadi gulma penting dan tumbuh secara mapan serta sangat merugikan (Tjitrosemito \& Kasno 1997). Menurut Tjitrosemito (1999), tumbuhan ini diperkirakan sudah tersebar di Indonesia sejak tahun 1910-an, dan pertama kali dilaporkan pada tahun 1934 di Lubuk Pakam, Sumatera Utara. Saat ini persebaran kirinyuh sudah sangat luas, meliputi Sumatera, Jawa, Kalimantan, Nusa Tenggara Timur, dan Papua (Prawiradiputra 2007).

Kirinyuh merupakan gulma yang sangat merugikan pada lahan pertanian, perkebunan, dan peternakan di Indonesia (SEAWIC 1991). Gulma ini dapat berkembang dengan cepat sehingga menimbulkan persaingan dengan tanaman lain untuk mendapatkan nutrisi, air, cahaya, dan ruang (Oppong-Anne \& Francais 2002). Selain itu, kirinyuh merupakan gulma penting pada lahan peternakan di Indonesia karena mampu membatasi wilayah penggembalaan ternak, penyebab keracunan ternak, pesaing rumput pakan, dan rawan kebakaran di musim kemarau (Torres \& Paller 1989).

Pengendalian kirinyuh di Indonesia telah dilakukan dengan berbagai cara (Prawiradiputra 2007) salah satunya dengan introduksi musuh alami lalat puru Cecidochares connexa Macquart (Diptera: Tephritidae) ke Indonesia pada tahun tahun 1995 pada beberapa daerah di Jawa Barat (Tjitrosemito 1998; Harahap 2006). Sampai saat ini, lalat puru telah menyebar secara alami khususnya di daerah Bogor, Jawa Barat (Sanjaya 2006).

Lalat puru dinilai dapat menurunkan jumlah cabang dan daun kirinyuh yang mengakibatkan pertumbuhan kirinyuh menjadi terhambat (McFadyen et al. 2003). Lalat puru dapat pula mengakibatkan penurunan produksi bunga dan biji sehingga menurunkan jumlah kirinyuh di alam (Orapa \& Bofeng 2004). Sementara itu, menurut Chenon et al. (2002), lalat puru kurang memberikan hasil yang memuaskan karena dari hasil pengamatan di lapangan memperlihatkan bahwa intensitas serangan lalat puru sangat tinggi terhadap setiap batang dan pucuk kirinyuh, namun keberadaan puru tersebut tidak mematikan gulma ini (Sanjaya 2006).

Pengendalian hayati tumbuhan eksotik dengan introduksi musuh alami kirinyuh dari daerah asalnya terkadang dinilai tidak berhasil dan bahkan memiliki dampak yang negatif terhadap serangga lokal (Pearson \& Callaway 2003). Pengendalian dengan inang tidak spesifik dapat menyebabkan dampak bukan target melalui pergantian fisik dan fungsional spesies lokal oleh agens hayati (Sanjaya 2006). Pengenalan spesies eksotik membutuhkan upaya pemantauan yang serius terutama pada daerah distribusi kirinyuh, keberadaan musuh alami setempat, dan spesies lain di habitat baru mereka. Tanpa pengawasan, degradasi keanekaragaman hayati dalam suatu ekosistem tidak terdeteksi terutama di daerah yang letaknya jauh dari titik pelepasan agens hayati (Harjaka 2010). 
Penelitian kirinyuh di Indonesia dalam kurun waktu 10 tahun terakhir hanya terbatas dengan melakukan uji ekstrak kirinyuh sebagai insektisida nabati (Thamrin 2014), sedangkan evaluasi pelepasan lalat puru di Bogor sebagai lokasi introduksi awal lalat puru telah dilakukan pada tahun 1996 (Tjitrosemito 1998). Untuk itu, perlu dilakukan penelitian terbaru tentang keberhasilan pelepasan lalat puru dalam mengendalikan kirinyuh di Indonesia dan asosiasi baru antara kirinyuh dengan komunitas serangga lokal selain lalat puru pada lokasi yang berbeda. Tujuan dari penelitian ini untuk mengetahui kemapanan lalat puru $C$. connexa di Indonesia serta mengetahui pengaruh tipe dan lokasi habitat terhadap serangan lalat puru pada kirinyuh $C$. odorata dan interaksinya dengan komunitas serangga lokal.

\section{BAHAN DAN METODE}

\section{Waktu dan tempat penelitian}

Penelitian dilaksanakan dari bulan Januari sampai Desember 2019. Pengambilan sampel dilakukan di lima desa Kecamatan Cigudeg, Kabupaten Bogor $\left(06^{\circ} 25^{\prime} 38.7\right.$ LS 106 $33^{\prime}$ '30.9BT) dan lima desa Kecamatan Penengahan, Kabupaten Lampung Selatan $\left(05^{\circ} 43^{\prime} 15.6\right.$ LS $105^{\circ} 41^{\prime}$ '08.4 BT) yang memiliki habitat perkebunan sawit dan habitat lahan terbuka. Kedua lokasi ini dipilih sebagai area yang mewakili daerah persebaran kirinyuh. Pemeliharaan puru dan identifikasi arthropoda dilakukan di Laboratorium Pengendalian Hayati, Departemen Proteksi Tanaman, IPB University dan Laboratorium Entomologi, Puslit Biologi, LIPI.

\section{Penentuan unit contoh}

Penentuan jumlah unit contoh yang diamati diperoleh dari penghitungan menggunakan metode kurva spesies area (KSA) (Scheiner 2003). Pengamatan dilakukan pada habitat lahan terbuka dengan cara membuat petakan berukuran $1 \mathrm{~m} \mathrm{x}$ $1 \mathrm{~m}$. Dari petak contoh dengan ukuran tersebut, dilakukan penghitungan jumlah tumbuhan kirinyuh dan serangga herbivor beserta musuh alami yang terdapat pada tumbuhan kirinyuh menggunakan hand vacuum. Setelah itu, dibuat petak dengan ukuran dua kali dari luasan semula, yaitu dengan ukuran $1 \mathrm{~m}$ x $2 \mathrm{~m}$ dan dilakukan kegiatan yang sama. Penambahan luasan dilakukan sampai dengan penambahan individu $\leq 10 \%$ (Scheiner 2003). Dengan menggunakan kurva ini maka dapat ditetapkan jumlah unit contoh yang dapat mewakili keadaan kirinyuh pada habitat yang akan diukur. Jumlah unit contoh yang digunakan pada pengamatan adalah sebanyak 30 unit contoh.

\section{Koleksi puru $C$. connexa}

Pengambilan sampel dilakukan dengan cara mengoleksi puru yang berasal dari kirinyuh secara purposive sampling pada setiap habitat di lokasi pengamatan. Koleksi puru dilakukan dengan cara memotong tangkai kirinyuh yang berpuru, kemudian dibersihkan dan dibawa ke laboratorium. Masing-masing puru diletakkan dalam wadah mika berdiameter $6 \mathrm{~cm}$ dan tinggi $10 \mathrm{~cm}$ yang bagian atasnya diberi kain organdi. Setiap wadah diberi label berisi nomor unit contoh, tanggal, dan lokasi pengambilan puru. Pemeliharaan (rearing) puru dilakukan selama satu bulan untuk melihat serangga yang keluar dari puru. Setelah itu, setiap puru dibedah untuk melihat jumlah lalat puru yang ada di dalam puru. Hasil yang diperoleh digunakan untuk menghitung frekuensi lalat puru pada setiap puru. Tingkat serangan lalat puru terhadap kirinyuh dihitung dengan rumus:

$$
\underset{\text { terserang }}{\% \text { tanaman }}=\frac{\text { Jumlah tanaman terserang puru }}{\text { Total tanaman keseluruhan }} \times 100 \%
$$

Rumus diatas digunakan untuk mengetahui seberapa besar serangan lalat puru pada kirinyuh di setiap lokasi dan habitat pengamatan. Tingkat parasitisasi puru yang terserang parasitoid dihitung dengan rumus sebagai berikut:

$$
\% \text { puru terparasit }=\frac{\text { Jumlah puru yang terparasit }}{\text { Total puru keseluruhan }} \times 100 \%
$$

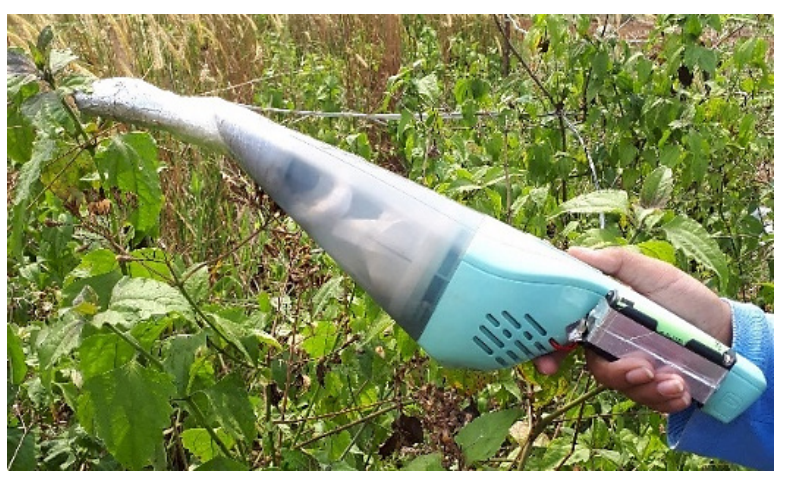

Gambar 1. Pengambilan sampel menggunakan hand vacuum. 


\section{Pengambilan sampel arthropoda yang ber- asosiasi dengan kirinyuh}

Sampel arthropoda diambil dengan menggunakan hand vacuum Lithium $3.6 \mathrm{~V}$ pada setiap unit tumbuhan kirinyuh per habitat per lokasi pengamatan. Pengambilan sampel dilakukan dengan cara menyedot arthropoda yang berada di pangkal hingga ujung batang kirinyuh menggunakan hand vacuum (Gambar 1).

Arthropoda yang sudah diambil menggunakan hand vacuum dipindahkan ke plastik sampel yang telah diberi label untuk dibawa ke laboratorium. Sampel arthropoda yang terkumpul di dalam plastik sampel dimatikan dengan menggunakan alkohol $70 \%$. Arthropoda yang terkumpul kemudian disortasi dan diidentifikasi hingga tingkat morfospesies untuk melihat keanekaragamannya.

\section{Identifikasi serangga}

Sampel arthropoda yang telah dikumpulkan disortir berdasarkan ordo, kemudian disortir kembali hingga tahap famili dan morfospesies. Satu individu morfospesies yang telah teridentifikasi dijadikan sebagai master untuk proses identifikasi selajutnya. Proses identifikasi menggunakan beberapa buku kunci identifikasi serangga, yaitu An Introduction to The Study of Insects: Sixth Edition (Borror et al. 1996), The Insect of Australia (CSIRO 1991), Manual of Nearctic Diptera Vol 1-2 (McAlpine 1987), Hymenoptera of The World: an Identification Guides to Families (Goulet \& Huber 1993), Biology and Management of Rice Insects (Heinrichs 1994), dan A Guide to The Beetles of Australia (Hangay \& Zborowski 2010).

\section{Analisis data}

Hasil yang diperoleh kemudian ditabulasikan ke dalam Microsoft Excel 2016. Perbedaan tingkat serangan lalat puru terhadap kirinyuh, jumlah puru, dan tingkat parasitisasi di kedua lokasi dan habitat dianalisis menggunakan ANOVA, sedangkan hubungan antara jumlah puru per tumbuhan dan jumlah lalat puru pada setiap puru terhadap lokasi dan habitat dianalisis menggunakan Chi-Square. Keseluruhan analisis dilakukan dengan perangkat lunak SAS 9.4.

\section{HASIL}

\section{Serangga yang berasosiasi dengan kirinyuh}

Berdasarkan hasil koleksi menggunakan hand vacuum, arthropoda yang ditemukan berasosiasi dengan kirinyuh di dua lokasi dan tipe habitat pengamatan, sebanyak 13.327 individu, terdiri atas 97 famili dan 256 morfospesies. Komposisi arthropoda yang didapat terdiri atas hama, predator, parasitoid, pengurai, dan beberapa serangga lain. Arthropoda yang yang ditemukan berasosiasi dengan kirinyuh di dua lokasi dan habitat pengamatan, sebanyak 53 morfospesies serangga yang berperan sebagai serangga herbivor (dalam kotak berwarna merah), 60 morfospesies serangga dan laba-laba berperan sebagai predator, dan 23 morfospesies serangga parasitoid (dalam kotak berwarna biru) (Gambar 2). Selain itu, ditemukan serangga dekomposer, serangga polinator, dan serangga lain (Tabel 1). Kelompok dominan berasal dari kelompok serangga herbivor sebanyak 9 morfospesies, kemudian kelompok arthropoda predator sebanyak 7 morfospesies, dan kelompok parasitoid sebanyak 6 morfospesies.

Berdasarkan diagram venn menunjukkan bahwa terdapat 26 morfospesies arthropoda yang dapat ditemukan pada semua habitat dan semua lokasi, dengan persentase $10,1 \%$ dari total spesies yang ditemukan. Hasil pengamatan menunjukkan bahwa terdapat arthropoda yang hanya ada pada masing-masing lokasi dan habitat pengamatan; dan arthropoda yang sama-sama ditemukan pada masing-masing lokasi dan habitat pengamatan (Gambar 3).

\section{Jenis serangga dari hasil koleksi puru}

Perbedaan lokasi pengamatan menimbulkan perbedaan interaksi antara kirinyuh dan komunitas arthropoda. Hasil pengamatan pemeliharaan puru menunjukkan terdapat spesies serangga yang keluar dari dalam puru selain $C$. connexa, yaitu lalat Lonchaea sp. (Diptera: Lonchaeidae). Lalat Lonchaea sp. hanya keluar dari dalam puru di Lampung pada habitat lahan terbuka. Selain itu, ditemukan juga musuh alami lalat puru dari kelompok parasitoid. Parasitoid yang ditemukan sebanyak 210 individu dari 13 morfospesies yang berasal dari Ordo Hymenoptera: Famili Bethylidae, Braconidae, Encyrtidae, Eucoilidae, Eulophidae, 


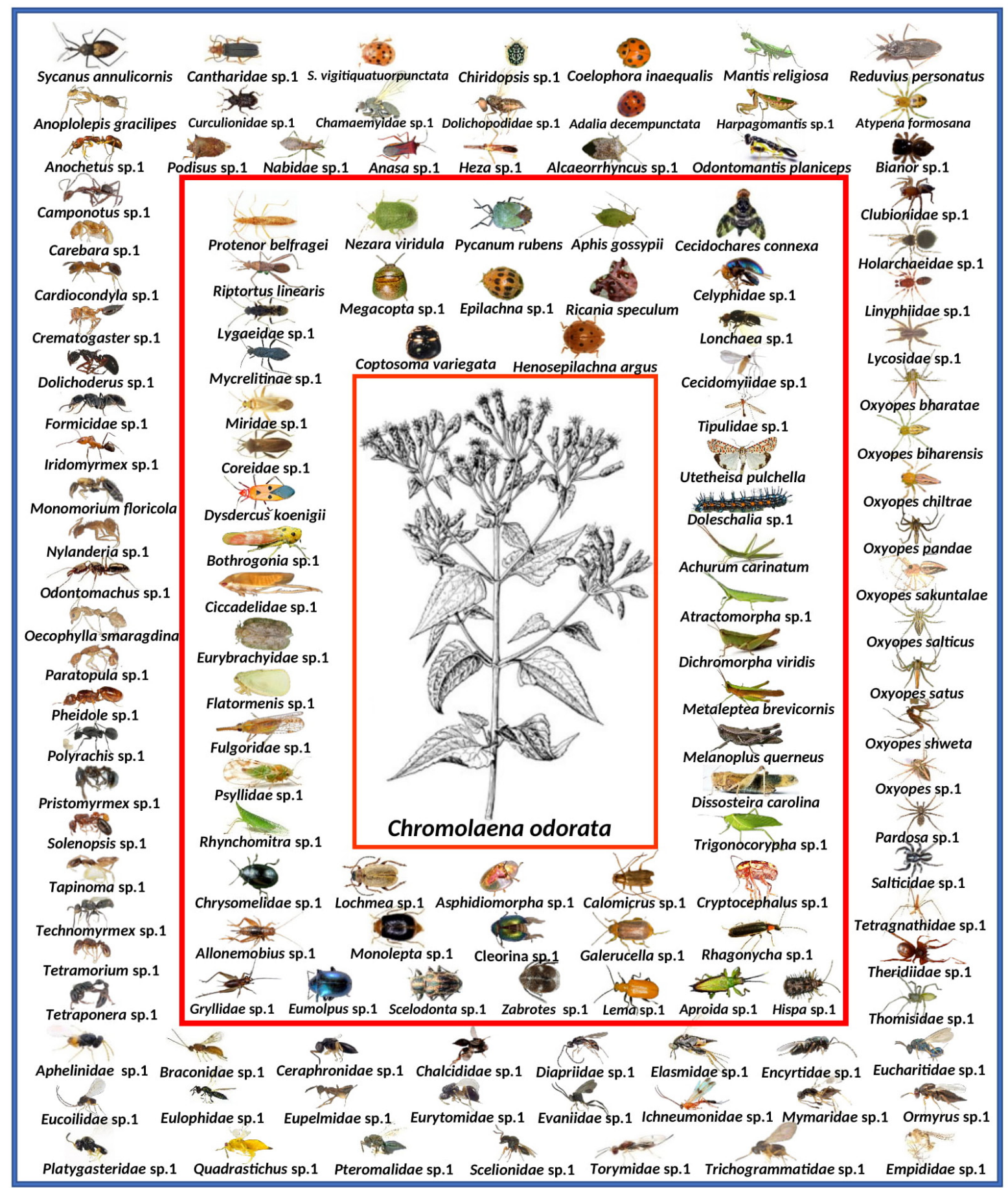

Gambar 2. Komunitas arthropoda yang berasosiasi dengan kirinyuh di Bogor dan Lampung. Kotak berwarna merah menggambarkan serangga herbivor, sedangkan kotak biru menggambarkan predator dan parasitoid.

Tabel 1. Jenis serangga lain dan peranannya yang diperoleh dari hasil hand vacuum di dua lokasi dan habitat pengamatan

\begin{tabular}{llll}
\hline Peranan & Ordo & Famili & Morfospesies \\
\hline Dekomposer & Diptera & Calliphoridae & Calliphoridae sp.1 \\
& Clusiidae & Clusiidae sp.1 \\
& Drosophilidae & Drosophillidae $\mathrm{sp} .1$ \\
& Lauxaniidae & Lauxaniidae $\mathrm{sp} .1$ \\
& Muscidae & Muscidae $\mathrm{sp} .1$ \\
& Phoridae & Phoridae sp.1 \\
\hline
\end{tabular}


Tabel 1. Jenis serangga lain dan peranannya yang diperoleh dari hasil hand vacuum di dua lokasi dan habitat pengamatan (Lanjutan...)

\begin{tabular}{|c|c|c|c|}
\hline Peranan & Ordo & Famili & Morfospesies \\
\hline \multirow[t]{8}{*}{ Polinator } & Lepidoptera & Erebidae & Amata sp. 1 \\
\hline & Hymenoptera & Ampulicidae & Ampulicidae sp.1 \\
\hline & & Mutilidae & Mutilidae sp.1 \\
\hline & & Pemphredonidae & Pemphredonidae sp.1 \\
\hline & & Spechidae & Spechidae sp.1 \\
\hline & & Syrphidae & Syrphidae sp.1 \\
\hline & & Tiphiidae & Tiphiidae sp.1 \\
\hline & & Vespidae & Vespidae sp.1 \\
\hline \multirow[t]{13}{*}{ Serangga lain } & Diptera & Ceratopogonidae & Ceratopogonidae sp.1 \\
\hline & & Chironomidae & Chironomidae sp.1 \\
\hline & & Chloropidae & Chloropidae sp.1 \\
\hline & & Culicidae & Culicidae sp.1 \\
\hline & & Pipunculidae & Pipunculidae sp.1 \\
\hline & & Scatopsidae & Scatopsidae sp.1 \\
\hline & & Sciaridae & Sciaridae sp.1 \\
\hline & & Tephritidae & Tephritidae sp.1 \\
\hline & Blatodea & Ectobiidae & Ectobiidae sp.1 \\
\hline & & Ectobiidae & Dictyoptera sp.1 \\
\hline & & Blattidae & Periplaneta sp.1 \\
\hline & Odonata & Libellulidae & Libellulidae sp.1 \\
\hline & Thysanoptera & Phlaeotripidae & Phlaeothripidae sp.1 \\
\hline
\end{tabular}

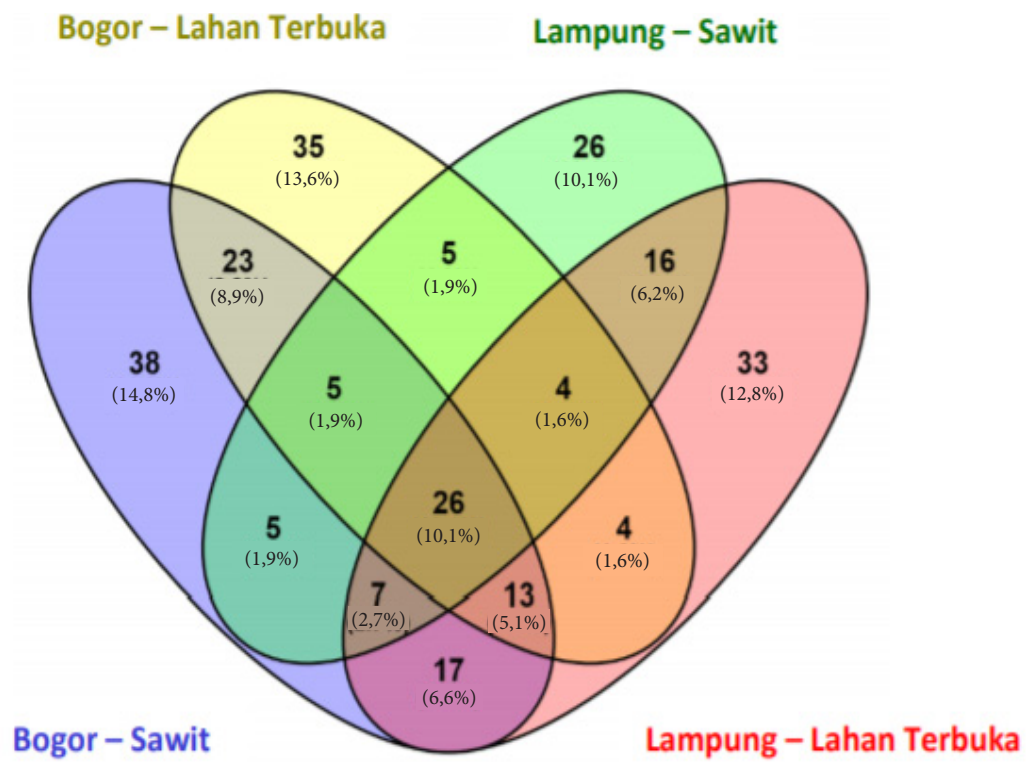

Gambar 3. Diagram venn yang menunjukkan kekayaan spesies arthropoda yang berasosiasi dengan kirinyuh pada tipe habitat dan lokasi berbeda. 
Eupelmidae, Eurytomidae dan Pteromalidae. Namun, parasitoid Encyrtidae belum dapat dikatakan sebagai parasitoid dari C. connexa karena dari hasil pemeliharaan puru Encyrtidae keluar dari dalam puru yang berisi C. connexa dan lalat Lonchaea sp. (Tabel 2). Sementara, di Bogor, kirinyuh hanya berasosiasi dengan $C$. connexa dan 3 famili serangga parasitoid Bethylidae, Pteromalidae, dan Eulophidae di dalam puru. Hal ini dapat diasumsikan bahwa ketiga parasitoid tersebut merupakan parasitoid dari C. connexa.

Interaksi tritrofik antara kirinyuh, lalat puru, dan musuh alami

Interaksi trofik yang terjadi pada kirinyuh terdiri atas tiga tingkatan trofik (tritrofik). Tingkatan trofik pertama adalah kirinyuh sebagai produsen. Tingkatan trofik kedua adalah serangga herbivor yang ditemukan pada lokasi penelitian, serangga herbivor tersebut termasuk lalat puru $C$. connexa dan serangga herbivor yang berasosiasi dengan kirinyuh, seperti kutu daun Aphis gossypii Glover, kepik Coptosoma variegata (Herrich-Schäffer), belalang Melanoplus brevicornis (Johannson), dan Atractomorpha sp. Tingkat trofik ketiga adalah musuh alami yang terdiri atas serangga predator, laba-laba, dan serangga parasitoid. Berdasarkan hasil pengamatan, kirinyuh telah berasosiasi dengan musuh alaminya, yaitu lalat puru dan komunitas arthropoda lokal di kedua lokasi dan habitat pengamatan.

Hasil pengamatan visual, kirinyuh telah berasosiasi dengan kutu daun $A$. gossypii dan kepik Coptosoma sp. yang ditemukan pada bagian pucuk kirinyuh dan menyebabkan daun berkeriting. Keberadaan kutu daun dapat menimbulkan asosiasi baru dengan predator lokal, yaitu semut dari genus Anoplolepis sp. dan Dolichoderus sp. (Hymenoptera: Formicidae) serta laba-laba dari genus Oxyopes sp. (Araneae: Oxyopidae). Semut Dolichoderus sp. mampu menjadi musuh alami dari C. connexa karena semut tersebut memangsa telur-telur $C$. connexa yang berada pada bagian pucuk kirinyuh. Selain itu, laba-laba Oxyopes sp. juga dapat berperan sebagai musuh alami dari C. connexa karena laba-laba tersebut memangsa larva dan pupa di dalam puru yang berjendela dan memangsa imago $C$. connexa yang terperangkap di jaring laba-laba.

Berdasarkan hasil pemeliharaan puru di Lampung, kirinyuh telah berasosiasi dengan $C$. connexa dan serangga herbivor lokal, yaitu lalat Lonchaea sp., sedangkan di Bogor tidak ditemukan. Keberadaan $C$. connexa yang berperan sebagai musuh alami dari kirinyuh, telah menimbulkan asosiasi baru dengan parasitoid lokal di dalam puru. Serangga parasitoid yang ditemukan di Bogor terdiri atas 3 famili, yaitu Bethylidae, Eulophidae dan Pteromalidae. Sedangkan parasitoid yang keluar dari dalam puru di Lampung terdiri dari 7 famili, yaitu Pteromalidae, Eulophidae, Eupelmidae, Eurytomidae, Eucoilidae, Encyrtidae, Braconidae (Gambar 4).

\section{Tingkat serangan lalat puru pada kirinyuh}

Hasil uji ANOVA menunjukkan bahwa lokasi Bogor dan Lampung berpengaruh secara signifikan terhadap serangan lalat puru pada

Tabel 2. Jenis serangga dan peranannya yang diperoleh dari hasil pemeliharaan puru Cecidochares connexa di dua lokasi dan habitat berbeda

\begin{tabular}{llll}
\hline Peranan & Ordo & Famili & Morfospesies \\
\hline Herbivor & Diptera & Tephritidae & Cecidochares connexa \\
& & Lonchaeidae & Lonchaea $\mathrm{sp}$. \\
Parasitoid & Hymenoptera & Bethylidae & Bethylidae $\mathrm{sp}$. \\
& Braconidae & Braconidae $\mathrm{sp} .01$, Braconidae $\mathrm{sp} .02$ \\
& Encyrtidae & Encyrtidae $\mathrm{sp}$. \\
& Eucoilidae & Eucoilidae $\mathrm{sp} .01$, Eucoilidae $\mathrm{sp} .02$, Eucoilidae $\mathrm{sp} .03$ \\
& Eulophidae & Quadrastichus $\mathrm{sp}$. \\
& Eupelmidae & Eupelmidae $\mathrm{sp}$. \\
& Eurytomidae & Eurytomidae $\mathrm{sp} .01$, Eurytomidae $\mathrm{sp} .02$ \\
& Pteromalidae & Pteromalidae $\mathrm{sp} .01$, Pteromalidae $\mathrm{sp} .02$ \\
\hline
\end{tabular}




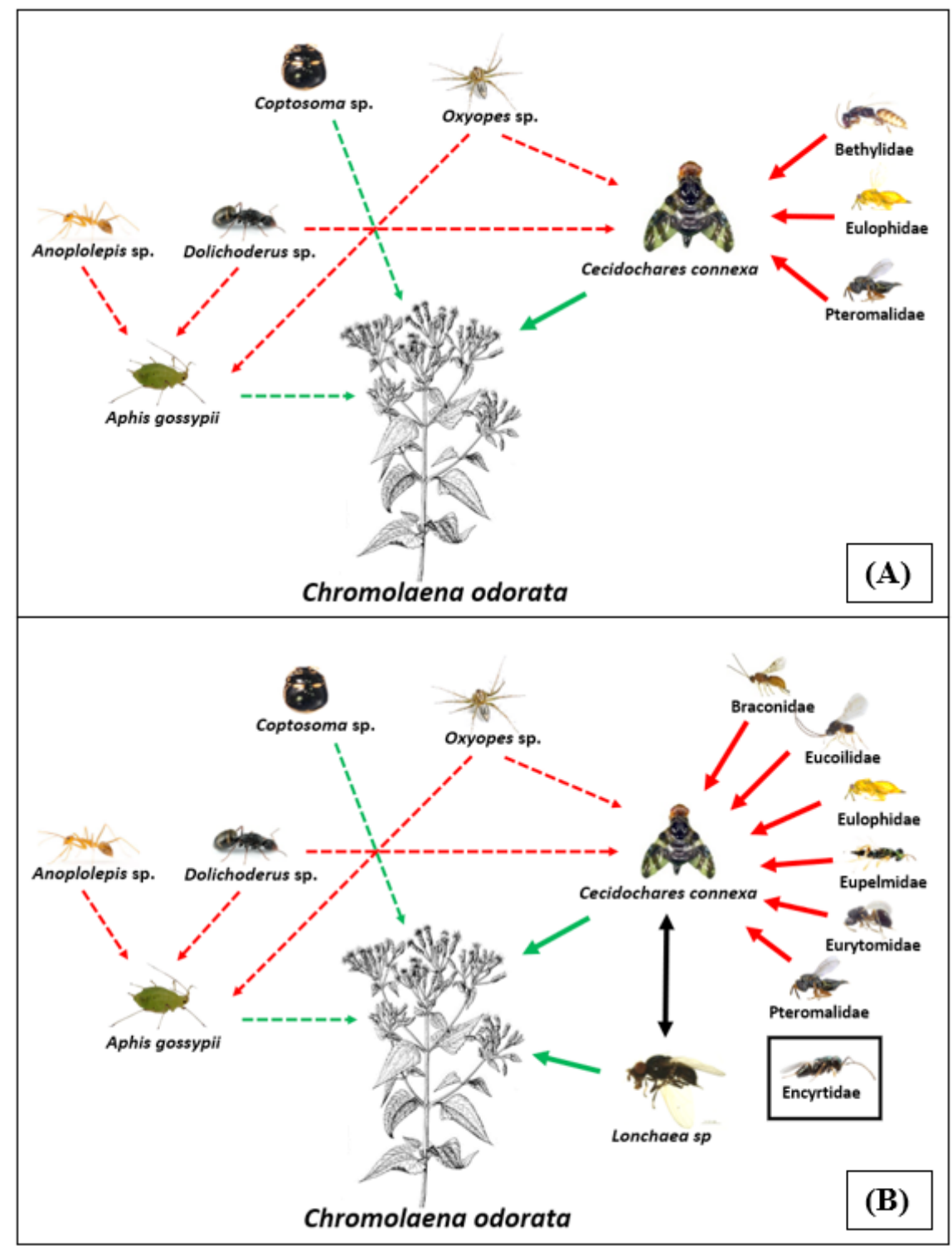

Gambar 4. Interaksi tritrofik antara kirinyuh, Cecidochares connexa dan musuh alaminya pada dua lokasi pengamatan Bogor (A) dan Lampung (B). Garis berwarna hijau menandakan serangga herbivor yang berasosiasi dengan kirinyuh, sedangkan garis berwarna merah menandakan arthropoda predator dan serangga parasitoid lokal yang telah berasosiasi dengan C. connexa dan serangga herbivor lokal. Garis tebal menunjukkan pengamatan pemeliharaan puru, sedangkan garis putusputus menunjukkan pengamatan visual di lapangan.

kirinyuh $\left(\mathrm{F}_{1,1}=7,650 ; \mathrm{P}=0,014\right)$. Namun, perbedaan habitat lahan terbuka dan kebun sawit tidak menunjukkan pengaruh yang signifikan $\left(\mathrm{F}_{1,1}=0,000 ; \mathrm{P}=0,963\right)$ (Tabel 3). Berdasarkan hasil analisis, tidak terdapat interaksi antara habitat dan lokasi $(\mathrm{F}=1,600 ; \mathrm{P}=0,224)$.

Berdasarkan hasil pengamatan 30 unit contoh tumbuhan yang diamati, rata-rata jumlah kirinyuh yang terserang puru di Lampung, yaitu sebanyak $22,80(76 \%)$ terserang puru, sedangkan di Bogor sebanyak 16,90 (56\%). Namun, berdasarkan tipe habitat, rata-rata jumlah kirinyuh yang terserang
Tabel 3. Rata-rata serangan puru pada tanaman kirinyuh pada dua tipe habitat di Bogor dan Lampung $(\mathrm{N}=30)$

\begin{tabular}{lcc}
\hline Faktor & Rerata \pm SD & $(\%)$ \\
\hline Lokasi & & \\
$\quad$ Bogor & $16,90 \pm 5,41 \mathrm{~B}$ & 56 \\
$\quad$ Lampung & $22,80 \pm 3,91 \mathrm{~A}$ & 76 \\
\hline Habitat & & \\
$\quad$ Lahan Terbuka & $19,90 \pm 7,06 \mathrm{a}$ & 66 \\
$\quad$ Kebun Sawit & $19,90 \pm 7,06 \mathrm{a}$ & 66 \\
\hline
\end{tabular}

Angka yang diikuti oleh huruf yang sama pada kolom yang sama tidak berbeda nyata berdasarkan uji selang berganda Tukey pada $\alpha=0,05$. 
puru menunjukkan hasil yang sama, yaitu sebanyak 19,90 (66\%) (Tabel 3). Hal ini menunjukkan bahwa tipe habitat tidak memengaruhi serangan lalat puru terhadap kirinyuh. Lalat puru telah mapan dan menyebar ke berbagai daerah termasuk Lampung yang belum pernah dilepaskan lalat puru.

\section{Jumlah puru $C$. connexa pada kirinyuh}

Hasil pengamatan jumlah puru menunjukkan bahwa lokasi $(\mathrm{F}=0,610 ; \mathrm{P}=0,446)$ dan habitat $(\mathrm{F}=1,030 ; \mathrm{P}=0,324)$ tidak berpengaruh signifikan terhadap serangan lalat puru pada kirinyuh. Berdasarkan hasil analisis tidak terdapat interaksi antara lokasi dan habitat $(\mathrm{F}=0,030 ; \mathrm{P}=0,854)$ terhadap serangan lalat puru pada kirinyuh. Ratarata jumlah puru pada kirinyuh di Lampung, yaitu sebanyak 135,10 puru, sedangkan di Bogor sebanyak 122,50 puru. Rata-rata jumlah puru di habitat sawit sebanyak 137 puru, sedangkan pada lahan terbuka sebanyak 120,60 puru (Tabel 4).

Tabel 4. Rata-rata jumlah puru Cecidochares connexa per tumbuhan kirinyuh pada dua tipe habitat di Bogor dan Lampung

\begin{tabular}{lcc}
\hline Faktor & Rerata \pm SD & $(\mathrm{N})$ \\
\hline Lokasi & & \\
$\quad$ Bogor & $122,50 \pm 4,80 \mathrm{~A}$ & 1.225 \\
$\quad$ Lampung & $135,10 \pm 3,91 \mathrm{~A}$ & 1.351 \\
\hline Habitat & & \\
$\quad$ Lahan Terbuka & $120,6 \pm 19,08 \mathrm{a}$ & 1.206 \\
$\quad$ Kebun Sawit & $137,0 \pm 45,18 \mathrm{a}$ & 1.370 \\
\hline
\end{tabular}

Angka yang diikuti oleh huruf yang sama pada kolom yang sama tidak berbeda nyata berdasarkan uji selang berganda Tukey pada $\alpha=0,05 ; \mathrm{N}$ : total jumlah puru dari unit tumbuhan yang terserang puru)

\section{Frekuensi puru yang terbentuk pada kirinyuh}

Berdasarkan pengamatan di lapangan menunjukkan frekuensi jumlah puru pada kirinyuh berkisar 1-18 puru per kirinyuh, namun terdapat satu kirinyuh dengan jumlah puru mencapai 28 puru pada habitat kebun sawit di Lampung (Tabel 5). Hal ini karena kirinyuh tersebut memiliki cabang yang banyak dan hampir seluruh cabang terinfestasi puru.

Hasil uji Chi Square menunjukkan terdapat hubungan yang signifikan antara jumlah puru per kirinyuh terhadap habitat dan lokasi pengamatan. Frekuensi sebaran jumlah puru kirinyuh lebih tinggi di Lampung dibandingkan dengan di Bogor. Hasil temuan ini menunjukkan bahwa jumlah puru per tanaman dipengaruhi oleh lokasi (Bogor dan Lampung) dan tipe habitat (kebun sawit dan lahan terbuka). Di Lampung pada habitat lahan terbuka, jumlah kirinyuh yang terserang puru lebih tinggi dibandingkan dengan di Bogor walaupun intensitas puru per tumbuhan relatif rendah, berkisar 1-3 puru per tumbuhan. Hal ini disebabkan oleh jumlah cabang per kirinyuh di Lampung lebih banyak dibandingkan dengan di Bogor sehingga jumlah pucuk kirinyuh yang digunakan sebagai tempat peletakan telur lalat puru yang kemudian menetas menjadi larva dan membentuk puru lebih banyak di Lampung dibandingkan dengan di Bogor. Frekuensi sebaran jumlah puru C. connexa per kirinyuh pada dua tipe habitat di Bogor dan Lampung dilihat pada (Tabel 5).

Puru hasil pemeliharaan di laboratorium dibedah untuk melihat jumlah lalat puru yang ada di dalam puru. Di dalam setiap puru terdapat 1-6 lalat puru (Tabel 6). Hasil uji Chi Square

Tabel 5. Jumlah puru Cecidochares connexa per tanaman kirinyuh pada habitat kebun sawit dan lahan terbuka di Bogor dan Lampung $(\mathrm{N}=600)$

\begin{tabular}{lcccccc}
\hline \multirow{2}{*}{ Jumlah puru } & \multicolumn{2}{c}{ Bogor } & \multicolumn{2}{c}{ Lampung } & \multirow{2}{*}{$X^{2}$} & P-Value \\
\cline { 2 - 5 } & Kebun Sawit & Lahan terbuka & Kebun Sawit & Lahan terbuka & & \\
\hline 0 & 59 & 72 & 43 & 29 & 10,3 & 0,007 \\
$1-3$ & 60 & 68 & 58 & 79 & & \\
$4-6$ & 24 & 9 & 25 & 28 & & \\
$7-9$ & 3 & 1 & 14 & 12 & & \\
$10-12$ & 3 & 0 & 5 & 2 & \\
$13-15$ & 0 & 0 & 4 & 0 & \\
$16-18$ & 1 & 0 & 0 & 0 & \\
$>18$ & 0 & 0 & 1 & 0 & & \\
\hline
\end{tabular}


Tabel 6. Jumah lalat Cecidochares connexa per puru pada habitat kebun sawit dan lahan terbuka di Bogor dan Lampung $(\mathrm{N}=1.587)$

\begin{tabular}{lcccccc}
\hline \multirow{2}{*}{ Jumlah lalat } & \multicolumn{2}{c}{ Bogor } & \multirow{2}{*}{ Lampung } & \multirow{2}{*}{ P-Value } \\
\cline { 2 - 5 } & Kebun sawit & Lahan terbuka & Kebun sawit & Lahan terbuka & & \\
\hline 1 & 198 & 152 & 298 & 252 & & \\
2 & 119 & 56 & 148 & 129 & & \\
3 & 38 & 23 & 49 & 55 & 15,292 & 0,43 \\
4 & 15 & 9 & 13 & 11 & & \\
5 & 2 & 2 & 6 & 7 & \\
6 & 1 & 0 & 3 & 1 & & \\
\hline
\end{tabular}

menunjukkan tidak terdapat hubungan yang signifikan antara jumlah $C$. connexa per puru terhadap habitat dan lokasi pengamatan.

Frekuensi sebaran jumlah lalat puru per puru dapat dilihat pada (Tabel 6). Hasil menunjukkan bahwa jumlah lalat puru per puru memiliki sebaran yang sama antar lokasi dan juga habitat sehingga sebaran jumlah lalat puru per puru tidak ditentukan oleh habitat dan juga lokasi. Puru yang dihuni oleh 1 lalat puru di kedua lokasi dan habitat pengamatan memiliki jumlah yang lebih tinggi dibandingkan lainnya. Hal ini menunjukkan bahwa jumlah lalat puru per puru tidak ditentukan oleh habitat dan juga lokasi. Namun, ukuran diameter dan tinggi puru dapat menyebabkan perbedaan isi lalat puru per puru.

\section{Tingkat parasitisasi $C$. connexa}

Hasil pengamatan menunjukkan bahwa tingkat parasitisasi puru berbeda secara signifikan antara di Bogor dan di Lampung $(\mathrm{F}=7,410 ; \mathrm{P}=$ 0,017). Namun, perbedaan habitat lahan terbuka dan kebun sawit $(\mathrm{F}=0,850 ; \mathrm{P}=0,6656)$ tidak menunjukkan pengaruh yang signifikan terhadap tingkat parasitisasi puru. Berdasarkan hasil pengujian interaksi pada lokasi dan habitat $(\mathrm{F}=$ 1,230; $\mathrm{P}=0,6956)$ tidak terdapat interaksi antara kedua perlakuan (Tabel 7).

Rata-rata tingkat parasitisasi puru di Lampung yang terserang parasitoid sebanyak 18,50 puru dengan presentase $13 \%$, sedangkan di Bogor sebanyak 5,80 puru dengan persentase $5 \%$. Serangan parasitoid pada setiap puru tidak dipengaruhi oleh perbedaan habitat (kebun kelapa sawit dan lahan terbuka), namun lokasi (Bogor dan Lampung) memengaruhi serangan parasitoid pada setiap puru. Parasitisasi puru oleh parasitoid tertinggi terjadi di Lampung dengan tingkat tingkat
Tabel 7. Tingkat parasitisasi puru Cecidochares connexa pada habitat kebun sawit dan lahan terbuka di Bogor dan Lampung

\begin{tabular}{lrrr}
\hline Faktor & \multicolumn{1}{c}{ Rerata \pm SD } & $(\%)$ & $(\mathrm{N})$ \\
\hline Lokasi & & & \\
$\quad$ Bogor & $5,80 \pm 4,01 \mathrm{~B}$ & 5 & 58 \\
$\quad$ Lampung & $18,50 \pm 13,79 \mathrm{~A}$ & 13 & 185 \\
Habitat & & & \\
$\quad$ Lahan Terbuka & $11,10 \pm 11,75 \mathrm{a}$ & 8 & 111 \\
$\quad$ Kebun Sawit & $13,20 \pm 12,48 \mathrm{a}$ & 9 & 135 \\
\hline
\end{tabular}

Angka yang diikuti oleh huruf yang sama pada kolom yang sama tidak berbeda nyata berdasarkan uji selang berganda Tukey pada $\alpha=0,05$; N: total jumlah puru yang terparasit oleh parasitoid secara keseluruhan.

parasitisasi dari setiap habitat, baik di lahan terbuka dan kebun sawit tidak jauh berbeda. Hal ini karena walaupun jumlah puru yang ditemukan di kedua lokasi tidak jauh berbeda, namun jumlah lalat puru yang ada di dalam puru di Lampung lebih banyak dibandingkan dengan di Bogor sehingga jumlah lalat puru yang terparasit lebih tinggi pula. Tingkat parasitisasi lalat puru di dalam puru berdasarkan tiap spesies parasitoid pada dua tipe habitat di Bogor dan Lampung dinilai cukup rendah (Tabel 7). Persentase parasitisasi berkisar antara 0 hingga $12,77 \%$ dengan persentase parasitoid paling tinggi berasal dari Famili Eulophidae mencapai 12,77\% di habitat kebun sawit Provinsi Lampung.

\section{PEMBAHASAN}

Hasil pengamatan memperlihatkan terdapat banyak spesies serangga yang berasosiasi dengan tumbuhan eksotik invasif $C$. odorata, seperti kutu aphid (Hemiptera: Aphididae), kepik C. variegata (Hemitera: Plataspididae), dan berbagai spesies 
belalang. Keberadaan kutu aphid pada pucuk muda C. odorata menyebabkan kehadiran koloni semut (Hymenoptera: Formicidae). Asosiasi semut dengan kutu aphid karena adanya eksresi embun madu (honey) kutu aphid yang dimanfaatkan oleh koloni semut. Keberadaan serangga herbivor eksotik juga akan berasosiasi dengan serangga lokal di habitat baru. Asosiasi serangga lokal terhadap lalat puru $C$. connexa yang terjadi di antaranya adalah musuh alami. Musuh alami ini terdiri atas predator dan parasitoid dari Ordo Hymenoptera, Coleoptera, Hemiptera, dan Diptera. Hal ini sesuai dengan penelitian Toisuta (2007), yang melaporkan terdapat 25 famili parasitoid yang ditemukan pada kirinyuh, beberapa di antaranya adalah Braconidae, Evaniidae, Eucoilidae, Proctotrupidae, Diapriidae, Scelionidae, Ceraphronidae, Chalcididae, Eurytomidae, Pteromalidae, Torymidae, Ormyridae, Eupelmidae, Encrytidae Eulophidae, Elasmidae, dan Mymaridae.

Serangan lalat puru C. connexa terhadap kirinyuh $C$. odorata tidak dipengaruhi oleh habitat pengamatan yang berbeda. Namun, lokasi pengamatan yang berbeda mempengaruhi tingkat serangan lalat puru terhadap kirinyuh, jumlah puru yang terbentuk pada setiap tumbuhan, tingkat parasitisasi puru oleh parasitoid, dan asosiasi dengan komunitas serangga lokal. Lokasi pengamatan di Bogor adalah lokasi pelepasan lalat puru, sedangkan Lampung sebagai lokasi yang belum pernah dilakukan pelepasan lalat puru. Berdasarkan hasil penelitian, tingkat serangan di Bogor lebih rendah dibandingkan dengan di Lampung. Rendahnya persentase kirinyuh yang terserang puru di Bogor dapat disebabkan adanya rutinitas pemangkasan gulma liar di perkebunan sawit. Sehingga, telur-telur yang diletakkan oleh imago betina lalat puru pada pucuk kirinyuh belum menjadi larva dan membentuk puru pada batang kirinyuh. Penyebab lainnya adalah adanya aktivitas predator yang memangsa larva lalat puru sesaat sebelum membuat puru pada batang kirinyuh. Hal ini sesuai dengan Indarwatmi (2006) yang menyatakan bahwa larva instar 1 yang baru keluar dari telur mudah diinfeksi oleh parasitoid dan dimangsa oleh predator karena masih berada pada permukaan pucuk dan daun-daun di pucuk mulai membuka. Keberadaan predator dari lalat puru dapat disebabkan karena lalat puru yang telah dilepaskan di Bogor sejak tahun 1995 sudah berasosiasi dengan komunitas serangga lokal termasuk musuh alami.

Tingginya jumlah puru per kirinyuh pada setiap lokasi dan habitat pengamatan tidak mempengaruhi pertumbuhan kirinyuh. Hal ini karena keberadaan lalat puru hanya untuk mengambil makanan dari dalam puru, dan tidak mematikan kirinyuh secara langsung. Sementara itu, kirinyuh memiliki sistem pertahanan diri dalam bentuk kompensasi dengan cara membentuk cabang lebih banyak pada batang yang terserang puru. Terbentuknya puru pada batang dan pucuk kirinyuh hanya dapat menghambat pertumbuhan kirinyuh saja. Hal ini sesuai dengan pendapat Chenon et al. (2002) bahwa intensitas serangan lalat puru yang sangat tinggi pada setiap batang dan pucuk kirinyuh, tidak akan mematikan tumbuhan tersebut.

Tingkat parasitisasi puru oleh parasitoid pada setiap tumbuhan kirinyuh di Lampung lebih tinggi dibandingkan dengan di Bogor, yaitu sebesar 13\%. Tingginya tingkat parasitisasi puru oleh parasitoid di Lampung dapat disebabkan jumlah lalat puru yang ada di dalam puru lebih banyak di Lampung dibandingkan dengan di Bogor, walaupun jumlah puru yang terdapat di Bogor dan Lampung tidak jauh berbeda sehingga menyebabkan jumlah lalat puru yang terparasit di Lampung lebih tinggi. Orapa \& Bofeng (2004) menyebutkan bahwa dalam satu tumbuhan gulma siam (Kirinyuh) dapat ditemukan 157 puru dan dalam satu puru dapat muncul rata-rata 1,7 individu lalat $C$. connexa.

Secara umum, lalat puru sebagai agens hayati kirinyuh yang diintroduksi dari Columbia telah mapan dan dapat beradaptasi dengan habitat baru, khususnya di Bogor. Namun, lalat ini belum cukup efektif untuk mengendalikan kirinyuh. Hal ini terlihat dari populasi kirinyuh di lapangan yang masih melimpah. Hal ini karena adanya aktifitas musuh alami dari lalat puru, baik parasitoid maupun predator. Musuh alami ini cenderung memengaruhi populasi lalat puru di alam dan pada akhirnya berdampak terhadap berkembangnya populasi kirinyuh yang merupakan inang dari lalat tersebut. Selain itu, kirinyuh juga mempunyai sistem pertahanan diri dengan membentuk cabang lebih banyak pada batang yang diserang lalat puru sebagai bentuk kompensasi. 


\section{KESIMPULAN}

Introduksi tumbuhan eksotik invasif $C$. odorata dan agens hayatinya $C$. connexa telah menyebabkan terjadinya asosiasi dengan komunitas serangga lokal. Adanya asosiasi tersebut mempengaruhi populasi lalat puru di alam yang kemudian berdampak terhadap semakin berkembangnya populasi kirinyuh yang merupakan inang dari lalat tersebut. Lokasi pengamatan mempengaruhi tingkat serangan lalat puru terhadap kirinyuh dan parasitisasi lalat puru oleh parasitoid, sedangkan habitat pengamatan tidak mempengaruhi keduanya.

\section{UCAPAN TERIMA KASIH}

Terima kasih disampaikan kepada Kementerian Riset Teknologi dan Pendidikan Tinggi (Kemenristekdikti) yang telah memberikan bantuan beasiswa dan mendanai penelitian ini melalui Beasiswa Program Magister menuju Doktor Sarjana Unggul tahun 2017.

\section{DAFTAR PUSTAKA}

Borror DJ, De Long DM, Triplehorn CA. 1981. An Introduction to the Study of Insect. New York: Saunders College Publishing.

Charles H, Dukes JS. 2008. Impact of invasif spesies on ecosystem services. Di dalam: Nentwig W (Ed.), Biological Invasions. Ecological Studies (Analysis and Synthesis). Vol. 193. hlm. 217237. Berlin, Heidelberg: Springer. doi: https:// doi.org/10.1007/978-3-540-36920-2_13.

Chenon RD, Sipayung A, Sudharto P. 2002. A decade of biological control against Chromolaena odorata at the indonesian oil palm research institute in Marihat. Di dalam: Zachariades C, Muniapan R, Strathie LW (Eds.), Proceedings of the Fifth International Workshop on Biological Control and Management of Chromolaena odorata (Durban, 23-25 Oktober 2000), hlm. 46-52. Pretoria: ARC-Plant Protection Research Institute.

Gautier L. 1992. Taxonomy and distribution of a tropical weed: Chromolaena odorata (L.) R. King \& H. Robinson. Candollea 47:645-662.
Goulet H, Huber JT. 1993. Hymenoptera of the World: An Identification Guide to Families. Ottawa: Canada Communication Group.

Harjaka T, Magoendihardjo S. 2010. Evaluasi lanjut penyebaran lalat argentina sebagai pengendali gulma siam. Jurnal Perlindungan Tanaman Indonesia 16:42-46.

Heinrichs EA. 1994. Biology and Management of Rice Insects. New Delhi: Wiley Eatern Limited.

Jose S, Kohli RK, Singh HP, Batish DR, Pieterson EC. 2009. Invasif plants: A threat to the integrity and sustainablity of forest ecosystems. Di dalam: Kohli RK, Jose S, Singh HP, Batis DR (Eds.), Inv Plants \& Forest Eco. hlm. 3-10. Boca Raton: CRC. Pr. doi: https://doi. org/10.1201/9781420043389.sec1.

Loveridge R, Wearn OR, Vieira M, Bernhard H, Ewers RM. 2016. Movement behavior of native and invasif small mammals shows logging may facilitate invasion in a tropical rain forest. Biotropica 48:373-380. doi: https://doi. org/10.1111/btp.12306.

McAlpine, Peterson, Shewell, Teskey, Vockeroth, Wood. 1987. Manual of Nearctic Diptera. Volume ke-1. Hull: Canadian Government Publishing Centre.

McFadyen REC, Chenon RD, Sipayung A. 2003. Biology and host specificity of the Chromolaena stem gall fly, Cecidochares connexa (Macquart) (Diptera: Tephritidae). Australian Journal of Entomology 42:294-297. doi: https://doi. org/10.1046/j.1440-6055.2003.00360.x.

Oppong-Anane K, Francais. 2002. Ghana Country Pasture/Forage Resource Profiles. Ghana: Ministry of Food and Agriculture, Accra-North, Ghana.

Orapa W, Bofeng I. 2004. Mass production, establishment dan impact of Cecidochares connexa on chromolaena on Papua New Guinea. Di dalam: Day MD, McFadyen REC(Eds.), Proceeding of the $6^{\text {th }}$ Workshop Chromolaena (Cairns, 6-9 May 2003). hlm 30-35. Canbera: ACIAR.

Pearson DE, Callaway RM. 2003. Efek tidak langsung dari host-spesifik agen kontrol biologis. Tren dalam Ekologi \& Evolusi 18:456-461. doi: https://doi.org/10.1016/S0169-5347(03)001885.

Pejchar L, Mooney HA. 2009. Invasif species, ecosystem services and human well-being. Trends in Ecology \& Evolution 24:497-504. doi: https://doi.org/10.1016/j.tree.2009.03.016. 
Prawiradiputra BR. 2007. Kirinyuh (Chromolaena odorata (L.) R.M. King dan H. Robinson): Gulma Padang Rumput yang Merugikan. Bogor: Balai Penelitian Ternak.

SanjayaAHJ.2006.ImplikasiEksistensi Chromolaena odorata (L.) Robinson (Asteraceae) dan Agens Hayatinya Cecidochares connexa Macquart (Diptera: Tephritidae) terhadap Struktur Komunitas Serangga dan Tumbuhan Lokal. Tesis. Bogor: Institut Pertanian Bogor.

Sheiner SM. 2003. Six Types of Special-Area Curves. New Jersey: Blackwell Science Ltd. doi: https:// doi.org/10.1046/j.1466-822X.2003.00061.x.

Harahap DSA. 2006. Penyebaran dan Kinerja Cecidochares connexa Sebagai Agen Pengendali Hayati Chromolaena odorata di Jawa Barat. Skripsi. Bogor: Institut Pertanian Bogor.

Hangay G, Zborowski P. 2010. A Guide to the Beatles of Australia. Collingwood, Victoria: CSIRO Publishing. doi: https://doi. org/10.1071/9780643100121.

Indarwatmi M. 2006. Biologi dan kisaran inang lalat puru Cecidochares connexa (Macquart) (Diptera: Tephritidae) sebagai agens hayati gulma kirinyuh. Tesis. Bogor: Institut Pertanian Bogor.

[SEAWIC] The Southeast Asian Weed Information Center. 1991. Chromolaena odorata (L.) R.M. King \& H. Robinson. Weed Info Sheet 5. Bogor: SEAMEO BIOTROP.

Thamrin M, Asikin S, Willis M. 2013. Tumbuhan kirinyuh Chromolaena odorata (L) (Asteraceae) sebagai insektisida nabati untuk mengendalikan ulat grayak Spodoptera litura. Jurnal Penelitan dan Pengembangan Pertanian 32:112-121.
Tjitrosemito S. 1998. Introduction of Procecidochares connexa (Diptera: Tephritidae) to Java Island to control C. odorata. Di dalam: Ferrar P, Muniappan R, Jayanth KP (Eds.). Proceeding of the Fourth International Workshop on the Biological Control and Management of Chromolaena odorata, (Bangalore, Oktober 1996). hlm. 6672. Guam: Agricultural Experiment Station, University of Guam. Tersedia pada: https://web. uog.edu/_resources/files/extension/publications/ Chromolaena_Odorata_1988.pdf [20 Desember 2019].

Tjitrosemito S, Kasno. 1997. Pengelolaan gulma terpadu pada hutan tanaman industri. Di dalam: Workshop Permasalahan Strategi Pengelolaan Hama di Areal Tanaman Hutan Industri (Bandungan, Semarang 17-19 Juni 1997).

Tjitrosemito S. 1999. The establishment of Procecidochares connexa in West Java, Indonesia: A biological control agent of Chromolaena odorata. Biotropia 12:19-24.

Toisuta JT. 2007. Keanekaragaman Hymenoptera Parasitoid pada Habitat Chromolaena odorata (L.) King \& Robinson (Asteraceae): Studi Parasitoid yang Berasosiasi dengan Cecidochares connexa Macquart (Diptera: Tephritidae) di daerah Bogor. Tesis. Bogor: Institut Pertanian Bogor.

Torres DO, Paller ECJr. 1989. The devil weed (Chromolaena odorata (I-.) R.M. King and H. Robinson) and its management. SEAWIC Weed Leaflet 4:1-6. 